\title{
The Collaborative Governance In The Devolopment Of Street Vendor Kanre' Rong Karebosi in Makassar City
}

\author{
Andi Samsu Alam ${ }^{1}$, Andi Muhammad Rusli ${ }^{2}$, Afni Amiruddin ${ }^{3}$, Andi Lukman Irwan ${ }^{4}$ \\ \{alamandi@rocketmail.com ${ }^{1}$, andirusli2727@gmail.com², afni.amiruddin@gmail.com ${ }^{3}$ \} \\ Faculty of Social and Political Sciences, Hasanuddin University, Jl. Perintis Kemerdekaan KM 10, \\ Makassar, 90245, Indonesia ${ }^{1,2,3,4}$
}

\begin{abstract}
This study aims to examine and analyze how the development of Street Vendors in the City of Makassar through the Kanre Rong Karebosi program and how the collaboration of the Makassar city government with the Bank BNI Makassar Region through the Kanre Rong Karebosi program in developing street vendors in Makassar City. The type of research used in this study is qualitative, which will provide a factual description of the Kanre Rong Karebosi program in Makassar City and the collaboration of the government and the Bank BNI Makassar Region.
\end{abstract}

Keywords: Implementation, Policy, Arrangement, Street Vendor.

\section{Introduction}

Makassar city government as the executor of a wide and responsible autonomous region, to regulate and take care of the interests of the local community according to the conditions and potential of the region [1]. The granting of autonomy to the regions is basically aimed at increasing the effectiveness and effectiveness of the implementation of regional governments, especially in carrying out development and services to the community based on Law Number 23 of 2014 concerning Regional Government.

The rise of street vendors (PKL) resulted in the emergence of various problems. There is an assumption that the existence of chaotic and irregular street vendors disturbs the order, beauty and cleanliness of the environment. Indiscriminate trading locations even tend to eat the lip of the road very disrupting traffic for both pedestrians and motorbike or car drivers [2]. In addition, irregular parking of buyers' vehicles is also very disturbing order. Not to mention the problem of waste or rubbish. During this time the street vendors have not been aware of the importance of cleanliness so that the beauty in the environment is difficult to realize. The quality of traded goods must also be considered, so that later it will not harm consumers.

Another factor contributing to the biggest traffic jam is street vendors. Inevitably the activities of street vendors, especially those around the streets in the city center that use road bodies contribute to congestion [3]. Congestion occurred filled with street vendors, pedestrians, and motorbikes. Not only that, the existence of street vendors also disrupts the beauty and order and regularity of city spatial planning. Several times the government has given warnings to street vendors who are still selling in urban centers will be subject to fines but still do not change the conditions of Makassar City. Although often evictions and 
relocations of land to sell street vendors sell, there are still many obstacles encountered including the number of street vendors who are more than the officials on duty and there are still many places where street vendors need relocation to realize a neat and orderly Makassar.

To deal with such conditions, a solution must be found by implementing the peddlers' policy system and the arrangement, strengthening of institutions and capital. If observed due to the embedded behavior patterns of the community such as: Human resources (HR) of low street vendors, the number of street vendors increasingly day by day, the location of the presence of street vendors who spread, and the implementation of weak control. For this reason, one of the efforts to reduce the negative impact of the current conditions is by designing the construction of a street vendor area [4].

Because of the need for the design of a street vendor area in Makassar, besides needing to get special attention, both from the local community and from the government so that it can make the city of Makassar an organized, beautiful and comfortable city. Based on the Makassar Mayor's regulation on the arrangement of street vendors, the Government established a street vendor arrangement program, namely providing stalls called Kaki Lima Ta 'and the area of street vendors called Kanrerong ri Karebosi [5]. This program is certainly an alternative place for the Makassar city government in allocating street vendors to realize a clean, neat and orderly city arrangement. The Street Vendor Program certainly provides facilities to street vendors such as booths / places to sell their wares. In addition, the government also provides venture capital for street vendors so that their merchandise can develop and provide the goods needed by the people of Makassar [6].

In its role the Government does not only rely on its internal capacity in the application of a policy and program implementation. However, there are limitations in capacity, resources and networks that support the implementation of a program or policy, thus encouraging the government to collaborate with various parties, both with fellow governments, private parties and the community and civil society communities so that cooperation can be established (Collaborative) ) and achieve program or policy goals. The need for the role of the stacholder in the implementation of the Makassar City Government's Progaram program therefore requires the role of the regional apparatus with the banks in developing the program [7]. How the role of local government with banks must relate (collaborate) in improving the street vendors. both of these sectors have a significant role in driving the increase and development of street vendors. Where the Government as regulator and Banking in providing business capital or capital loans.

In developing the program, the Makassar city government cooperated among relevant stakeholders, which involved the role of government and banking. The street vendor development program deals with various sectors of the business process that is carried out, so that it requires the role of various stakeholders. The success of the street vendor development program depends on how stakeholders carry out the program in accordance with their main tasks and functions [8]. The development of street vendors also depends on how the government can collaborate with various stakeholders for the realization of the development of street vendors in the Kanre rong karebosi area [9].

\section{Research Method}

In this study, researchers used a qualitative approach. A qualitative approach is used on the grounds that qualitative research is not obtained through statistical procedures or other 
forms of calculation. The research locations are Makassar City Cooperatives and SMEs Office, Makassar City Public Works Office, the Department of Trade and the UPTD Makassar City business services.

In this study data were obtained from informants who were directly involved in establishing cooperation in the development of the street vendors Kanre Rong Karebosi in Makassar City, including: Staff in the section of construction of government buildings, UPTD Head of integrated service center Kanre Rong Karebosi, Head of UKM Development, Head of SME Department of Commerce, street vendors at the location of Kanong Rong Karebosi. Data is also obtained through events or phenomena that occur at the research location in accordance with the focus of the study. Other data sources are documents relating to the focus of research. Data collection techniques used are interviews, observation, and documentation.

Data analysis techniques in this study used qualitative technical analysis, meaning that the data was obtained systematically, by collecting data and facts about research studies to then be reviewed and analyzed in the form of interpretation of the data obtained. There are three activities in data analysis, namely: data reduction, data display, and conclusion drawing / verification [10].

\section{Result And Discussion}

Based on Makassar Mayor Regulation No. 29 of 2018 concerning street vendors Kanre rong Karebosi in general terms that the service that houses the street vendors Kanrerong Karebosi is the Office of Cooperatives, small businesses and middle of the city of Makassar, then the formation of a technical implementing unit of the service center of the business center in the aisle is called UPTD-PLUL is an element of the technical implementing agency that carries out operational technical activities or certain supporting technical activities. Then the cultivation of the street vendor Karebosi is an effort of the Makassar city government to grow the creative business of street vendors in the city of Makassar.

The implementation of government policies is carried out with rational and proportional thinking. The logic of the government in issuing policies in this case relocation and empowerment, it is the government trying to find a win-win solution for the problem of street vendors. With the issuance of a relocation and empowerment policy, the government can realize a beautiful and clean urban planning, but it can also empower the presence of street vendors to support the regional economy. As for the impact felt by street vendors Empowering street vendors through relocation is aimed at formalizing informal actors, meaning that by placing street vendors on the stalls provided, street vendors are legal according to the law.

In implementing policies, it is very necessary to directly involve the government and stakeholders so that the development of street vendors can be carried out in accordance with mutual understanding between the parties. The policy on structuring and developing street vendors is a mandate from the Minister of Domestic Affairs regulation number 41 of 2002 regarding guidelines on structuring and empowering street vendors. With the involvement of all parties related to the problems of street vendors, a solution can be found through the development of street vendors, namely Kanre Rong Karebosi and issuing a memorandum of understanding between the Makassar city government and the Makassar region Bank Nasional Indonesia (BNI) in the form of financial assistance or soft fees for street vendor. The relocated of street vendors in Kanre Rong Karebosi s is in accordance with the concept of collaborative governance put forward by Donahue and Zeckhauser [2] that; the conditions under which the 
government meets public objectives through collaboration between organizations and individuals. This is in line with the expression by Holzer [2] which states that collaborative governance is a condition when the government and the private sector strive to achieve common goals for society.

The innovation created by the Makassar city government is the Kanrerong Program which is a form of effort by the city government to carry out the arrangement and empowerment of street vendors in Makassar. In addition, the government will also pay attention to aspects of promotion, marketing, training guidance, and ease of business capital. Through kanrerong the street vendors are expected to run their businesses thinnest, safer and more comfortable. Thus, the presence of Kanrerong for street vendors is certainly part of the creation of a thin and safe urban spatial plan and the government involving banks as part of the collaborative governance theory according to Emarson, Nabatchi and Balogh [2], namely in answering work processes involving government and actors who is able to solve common problems. To answer the involvement between the Makassar city government and the BNI Bank in Makassar, it can be stated through a collaborative governance theory (CGR) theory that explains in detail how the process of collaboration is dynamic and multi-cycle. The collaboration process in question is in the CGR box.

\subsection{The Dynamics of the Collaboration Between the Makassar City Government and BNI Region Makassar}
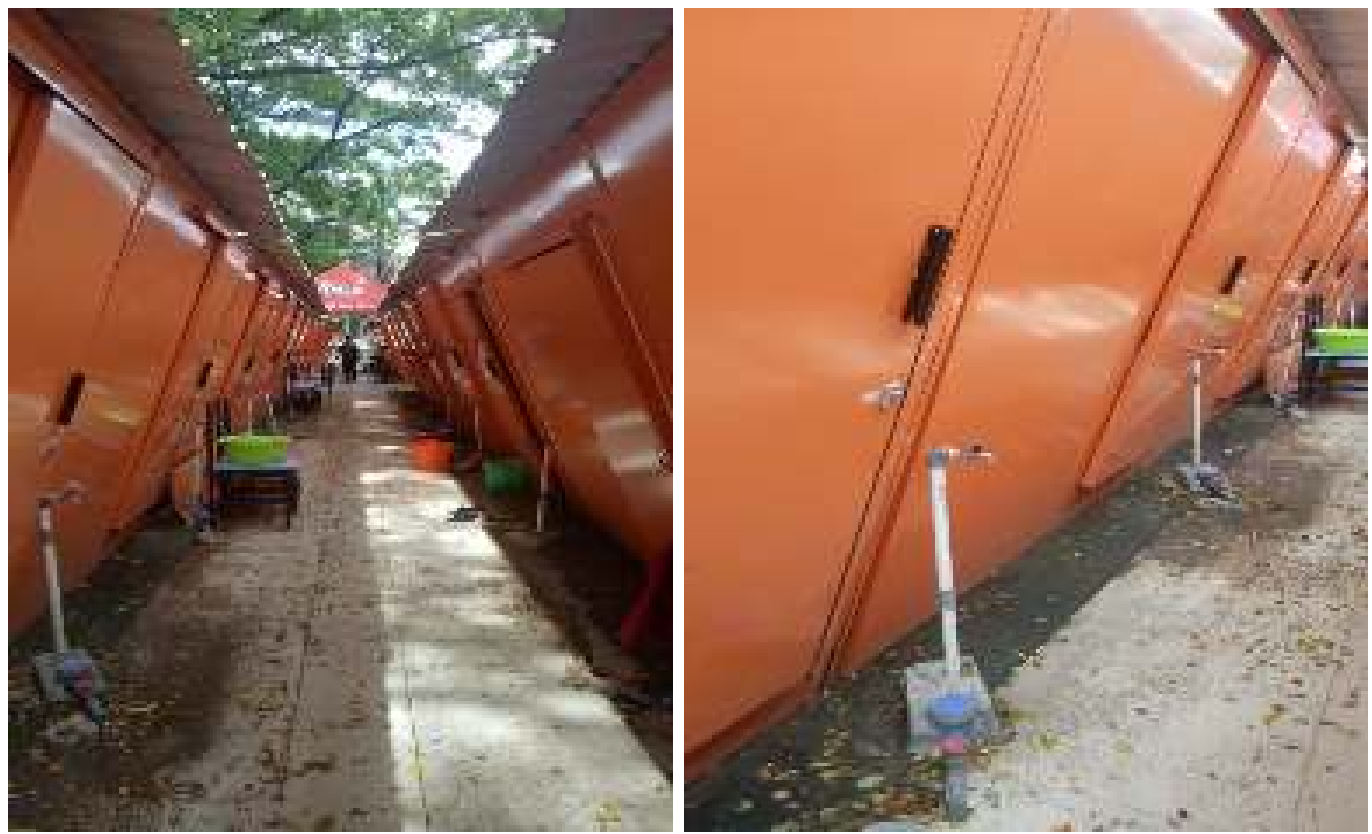

Fig. 1. Existing facilities and infrastructure at the location of Kanrerong Ri Karebosi

In the discussion of the dynamics of the collaborative process as an operative interaction cycle. The author refers to Emerson [2], which focuses on three interaction components of the dynamics of collaboration. These components include: Principled 
engagement, shared motivation and capacity for joint action. Then the researcher will explain according to the results of the field research. As follows:

\subsubsection{Mobilization of Principled Engagement}

Table 1. Data Relocation of street vendors in Kanrerong ri Karebosi District

\begin{tabular}{clc}
\hline No & \multicolumn{1}{c}{ Sub-District } & Number of Street Vendors \\
\hline 1. & Ujung Pandang & 76 persons \\
2. & Rappocini & 45 persons \\
3. & Bontoala & 87 persons \\
& $\quad$ Total & 218 persons \\
\hline
\end{tabular}

The efforts of the Makassar City Agency of Cooperation and Small Enterprises (KUKM Agency) in collaboration with the BNI Bank in the Makassar region through cooperation in assisting street vendors to develop, manage and maintain their businesses so that they are expected to become strong and independent entrepreneurs by providing capital assistance. Capital assistance can be channeled through revolving capital. The Makassar City Government's commitment in promoting the business of the street vendor is highly eroded, based on the signing of a Memorandum of Understanding on cooperation of soft financing partnerships for the street vendors implemented in accordance with applicable laws and regulations.

\subsubsection{Shared Motivation}

There is trust in the implementation of Collaboration carried out between the Makassar City government and PT Bank BNI Makassar Region, in an effort to develop Street Vendors. Important collaboration is carried out to help each other between government agencies and other institutions with their respective roles to overcome problems faced by street vendors such as:

- Limited capital

- Limited raw materials

- Limited marketability and promotion

The Makassar City Government responded by establishing cooperation with the Makassar Region BNI Bank to deal with problems or limitations faced by street vendors by making efforts, namely Provision of Business Capital.

Table 2. Recipients of Soft financing Assistance

\begin{tabular}{lllll}
\hline No & Name & Type of business & Origin District & $\begin{array}{c}\text { Amount of } \\
\text { funds }\end{array}$ \\
\hline 1 & Emil & Food/Beverage & Bontoala & 4.000 .000 \\
2 & Nurbaya & Food/Beverage & Bontoala & 4.000 .000 \\
3 & Nurayati & Food/Beverage & Bontoala & 4.000 .000 \\
\hline
\end{tabular}




\begin{tabular}{lllll}
\hline 4 & Hafsah & Food/Beverage & Bontoala & 5.000 .000 \\
5 & $\mathrm{JH}$ & Food/Beverage & Bontoala & 4.000 .000 \\
\hline
\end{tabular}

\subsubsection{Capacity for Joint Action}

The main objective of collaboration is to produce the desired outcome together so that the capacity building of street vendors in Makassar will be supported by banks. Bank BNI Makassar Region which aims to channel assistance in the form of soft financing for street vendors. Makassar City Government, Bank BNI Makassar Region will form an ecosystem of street vendors who are literate in banking products. This commitment is evidenced in the cooperation agreement signed by the Makassar Region BNI Bank and the Makassar City Government. The government, in this case the Makassar City Cooperative and SME Office, collaborated with the BNI Bank Region of Makassar City marked by the Signing of the Memorandum of Understanding Number: 180.511.3 / 09 / BPKS / III / 2019. In the implementation of this collaboration, it can be concluded that the collaboration process of the Makassar City Government and the BNI Bank of the Makassar City Region in developing street vendors in Makassar City has fulfilled the Collaborative Governance Regime (CGR) component. The Makassar Region Bank BNI provides the facilities provided not only in the form of soft credit but also assistance or capacity building to the Street Vendor.

Table 3. Street vendor income / income (PKL)

\begin{tabular}{cllcc}
\hline No & Name & Type of Sales & $\begin{array}{c}\text { Daily Income } \\
\text { (in the old place) }\end{array}$ & $\begin{array}{c}\text { Daily Income } \\
\text { (in a new place) }\end{array}$ \\
\hline 1 & Ani & Food/Beverage & $500.000-1.000 .000$ & 300.000 \\
2 & Ramlah & Food/Beverage & 500.000 & inconsistent \\
3 & Leha & Food/Beverage & $500.000-1.000 .000$ & 200.000 \\
4 & Irma & Food/Beverage & 800.000 & 300.000 \\
5 & Yuyu & Food/Beverage & 3.000 .000 & 300.000 \\
6 & Jumriwati & Food/Beverage & 500.000800 .000 & $200.000-400.000$ \\
7 & Rahmatia & Food/Beverage & 500.000 & $100.000-200.000$ \\
8 & Lina & Food/Beverage & 700.000 & $100.000-200.000$ \\
9 & Sitti & Food/Beverage & $800.000-1.000 .000$ & 400.000 \\
\hline
\end{tabular}

\section{Conclusion}

Based on the results of research and discussion related to governance collaboration in the development of street vendors in the city of Makassar, it can be concluded that it can be concluded as follows: Makassar city government through Makassar Mayor Regulation Number 29 of 2019. Implementing the Kanrerong program which is a special area for street vendors from Ujung Padang, Rappocini and Bontoala districts. The Kaki limata and Kanrerong Program is a form of effort by the Makassar city government to carry out the structuring and empowerment of street vendors in Makassar. The presence of Kaki Limata and Kanrerong for street vendors is certainly part of the creation of a city layout that is thin and 
safe and is suitable for street vendors. In implementing the policy of the city government in this case the UKM Agency collaborates with the Makassar City Bank BNI marked by the Signing of the Memorandum of Understanding Number: 180.511.3 / 09 / BPKS / III / 2019. In the implementation of this collaboration, it can be concluded that the collaboration process of the Makassar City Government and the BNI Bank of the Makassar City Region in developing street vendors in Makassar City has fulfilled the Collaborative Governance Regime (CGR) component.

By looking at the results of the study, the writer can conclude that the work plans of the two collaborating parties are found in common namely optimal running, both parties equally want to develop a street vendors which is in the area of Kanrerong ri karebosi which is a culinary tourism center. The similarity of the two plans which then becomes a reference for both parties to collaborate with each other so that collaboration in planning the development of street vendors has been running quite optimal. Both collaborations have been able to maintain the continuity of both the Makassar city government and PT Bank BNI between the two parties during collaboration.

\section{References}

[1] Aggranoff, R.: Inside Collaborative Networks: Ten Lessons For Public Managers.,“ Public Administration Review, zv. 66(1) pp. 56-65 (2006)

[2] Agranoff, R,. McGuire, M.: Collaborative Public Management: New Strategies for Local Governments, Georgetown University Press p. 232. (2003)

[3] Ali F. A., Alam, S.: Studi Kebijakan Pemerintah. Jakarta: Refika Aditama (2012)

[4] Ali F. A., Alam, S., Wantu, S.: Studi Analisa Kebijakan, Jakarta: Refika Adimati (2012)

[5] Haris a S. (Ed.).: Desentralisasi dan Otonomi Daerah (Desentralisasi, Demokratisasi dan Akuntabilitas Pemerintah Daerah), Jakarta: LIPI Press (2005)

[6] Thomson a, A. M., Perry, J. L.: Collaboration Processes: Inside the Black Box,“ Public Administration Review, 66 pp. 20-32 (2006)

[7] Rilley, J. M.: Stakeholders in rural development: Critical collaboration in state-NGO partnerships, Sage (2002)

[8] Soenarko, H.: Public Policy, Surabaya: Airlangga University (2003)

[9] Subarsono, A.: Kebijakan Publik dan Pemerintahan Kolaboratif Isu-Isu Kontemporer, Yogyakarta: Gava Media (2016)

[10] Tangkilisan a, H. N. S., Saputro, S. H.: Implementasi kebijakan publik: transformasi pikiran George Edwards, Lukman Offset: Yayasan Pembaruan Administrasi Publik Indonesia (YPAPI) (2003) 